\title{
Thalassobacillus cyri sp. nov., a moderately halophilic Gram-positive bacterium from a hypersaline lake
}

Correspondence

A. Ventosa

ventosa@us.es

\author{
C. Sanchez-Porro, ${ }^{1}$ M. A. Amoozegar, ${ }^{2}$ R. Rohban, ${ }^{3}$ M. Hajighasemi ${ }^{2}$ \\ and A. Ventosa ${ }^{1}$
}
${ }^{1}$ Department of Microbiology and Parasitology, Faculty of Pharmacy, University of Sevilla, 41012 Sevilla, Spain
${ }^{2}$ Extremophiles Lab; Department of Microbiology, Faculty of Biology, College of Science, University of Tehran, Tehran, Iran
${ }^{3}$ Department of Biology, Islamic Azad University, Science and Research Campus, Tehran, Iran

Moderately halophilic bacteria are defined as those that grow optimally in media containing 3-15\% (w/v) $\mathrm{NaCl}$ and such bacteria are widely distributed in hypersaline habitats (Ventosa et al., 1998). They are represented by heterogeneous physiological and taxonomic groups including both Gram-negative and Gram-positive micro-organisms (Ventosa et al., 1998; Ventosa, 2006). Among the Gram-positive examples, several aerobic, endospore-forming halophilic genera and species have been reported (Arahal \& Ventosa, 2002; Ventosa, 2006). The genus Thalassobacillus was proposed by García et al. (2005) for Gram-positive, endospore-forming motile rods that are moderately halophilic and have cell-wall peptidoglycan of

The GenBank/EMBL/DDBJ accession number for the 16S rRNA gene sequence of strain $\mathrm{HS} 286^{\top}$ is FM864226. type A1 $\gamma$, with meso-diaminopimelic acid as the diagnostic diamino acid. The major fatty acids of members of this genus are anteiso- $C_{15: 0}$, iso- $C_{16: 0}$ and iso- $C_{15: 0}$, the predominant menaquinone is $\mathrm{MK}-7$ and the $\mathrm{G}+\mathrm{C}$ content of the DNA is $42.4 \mathrm{~mol} \%$. This genus is currently represented by a single species, Thalassobacillus devorans, which is able to degrade phenol and other aromatic compounds and was isolated from a saline soil in South Spain. Based on the comparison of the 16S rRNA gene sequence, this species is phylogenetically related to species of the genus Halobacillus; however, in contrast to $T$. devorans, a key characteristic of species of the genus Halobacillus is a cell-wall peptidoglycan type based on OrnD-Asp (Spring et al., 1996). The aim of the present study was to determine the taxonomic position of strain $\mathrm{HS} 286^{\mathrm{T}}$, isolated from a hypersaline lake in Iran, by using a 
polyphasic approach. The results presented here show that this isolate represents a novel species of the genus Thalassobacillus.

Strain HS286 ${ }^{\mathrm{T}}$ was isolated from water of the hypersaline lake Howz-Soltan, which is located near Qom city in the centre of Iran, with an extent of about 240 and $280 \mathrm{~km}^{2}$ in dry and wet seasons, respectively. The depth of the salt layer, which covers almost all the surface of the lake bed (playa), varies between $20-46 \mathrm{~m}$ and the $\mathrm{pH}$ of the water, saline soil and salt sediments ranges between 6.5 and 8.2. The major chemical composition of the soil, brine, mud and salt consists of $\mathrm{NaCl}, \mathrm{KCl}, \mathrm{MgSO}, \mathrm{MgCl}_{2}$ and $\mathrm{Na}_{2} \mathrm{SO}_{4}$. At the time of sampling, the temperature of the water was $32{ }^{\circ} \mathrm{C}$ and the $\mathrm{pH}$ was 7.6. Strain $\mathrm{HS} 286^{\mathrm{T}}$ was isolated by diluting a water sample in sterile $10 \%(\mathrm{w} / \mathrm{v})$ salt solution, plating on $10 \% \mathrm{HM}$ medium and incubation at $37{ }^{\circ} \mathrm{C}$ aerobically. The $10 \% \mathrm{HM}$ medium contained $\left(\mathrm{l}^{-1}\right): 81 \mathrm{~g}$ $\mathrm{NaCl}, 7 \mathrm{~g} \mathrm{MgCl}_{2}, 9.6 \mathrm{~g} \mathrm{MgSO}_{4}, 0.36 \mathrm{~g} \mathrm{CaCl}_{2}, 2 \mathrm{~g} \mathrm{KCl}$, $0.06 \mathrm{~g} \mathrm{NaHCO}_{3}, 0.026 \mathrm{~g} \mathrm{NaBr}, 5$ g proteose-peptone no. 3 (Difco); $10 \mathrm{~g}$ yeast extract (Difco) and $1 \mathrm{~g}$ glucose (Ventosa et al., 1982). The $\mathrm{pH}$ of this medium was adjusted to 7.5. The strain was subsequently purified three times by plating on the same medium and was maintained on the same $\mathrm{HM}$ medium and at $-80{ }^{\circ} \mathrm{C}$ on $\mathrm{HM}$ medium without agar and supplemented with $30 \%(\mathrm{v} / \mathrm{v})$ glycerol.

In order to characterize strain $\mathrm{HS}_{2} 26^{\mathrm{T}}$ phenotypically, standard tests were performed. Cell morphology was examined by light microscopy (model CX31; Olympus) using cells from exponentially growing cultures. Gram staining was performed by the Burke method (Murray et al., 1994) and the result was confirmed by the $\mathrm{KOH}$ test (Baron \& Finegold, 1990). The presence of endospores was investigated by using the Schaeffer-Fulton staining method (Murray et al., 1994). Motility was analysed by the wetmount method (Murray et al., 1994). Catalase, oxidase and urease activities, nitrate reduction, hydrolysis of aesculin, production of indole and methyl red and Voges-Proskauer reactions were tested as recommended by Smibert \& Krieg (1994). Hydrolysis of Tween 80 was examined as described by Harrigan \& McCance (1976). Determination of acid production from carbohydrates, as well as utilization of carbon and nitrogen sources, was performed as recommended by Ventosa et al. (1982). Antibiotic susceptibility tests were performed on plates of Mueller-Hinton agar plus $10 \%(\mathrm{w} / \mathrm{v})$ sea salts seeded with a bacterial suspension containing $1.5 \times 10^{6}$ c.f.u. $\mathrm{ml}^{-1}$ using discs (HiMedia) impregnated with various antibiotics. The plates were incubated at $37{ }^{\circ} \mathrm{C}$ for $48 \mathrm{~h}$ and the inhibition zone was interpreted according to the manufacturer's manual. To determine the optimal temperature and $\mathrm{pH}$ for growth of the novel strain, broth cultures were incubated at temperatures of $10-50{ }^{\circ} \mathrm{C}$ at intervals of $5{ }^{\circ} \mathrm{C}$ and at $\mathrm{pH} 5-11$ at intervals of $0.5 \mathrm{pH}$ units. $\mathrm{pH}$ values below 6 , pH 6-9 and $\mathrm{pH}$ values above 9 were obtained using sodium acetate/acetic acid, Tris/ $\mathrm{HCl}$ and glycine/sodium hydroxide buffers, respectively. Growth at different salt concentrations $(0,1,2.5,5,8,10,15,20$ and $25 \%$, w/v) was tested on HM medium at $\mathrm{pH}$ 7.5. Growth was monitored by turbidity at $\mathrm{OD}_{600}$ using a spectrophotometric method (model UV-160 A; Shimadzu). Other physiological and biochemical tests were performed as described previously (Mata et al., 2002; Quesada et al., 1984; Ventosa et al., 1982).

Cells of strain $\mathrm{HS}^{2} 86^{\mathrm{T}}$ were Gram-positive, motile and strictly aerobic. They were able to produce ellipsoidal endospores at a central to subterminal position in swollen sporangia. The new isolate was moderately halophilic, showing optimal growth at $8 \%(\mathrm{w} / \mathrm{v}) \mathrm{NaCl}$ and being able to grow in media with $1-15 \%(\mathrm{w} / \mathrm{v}) \mathrm{NaCl}$. It was not able to grow in media without $\mathrm{NaCl}$. Other phenotypic features are included in Table 1 and are detailed in the species description.

Genomic DNA from strain HS286 ${ }^{\mathrm{T}}$ was obtained using the method described by Marmur (1961). The 16S rRNA gene of the strain was amplified by PCR using the forward primer 16F27 and the reverse primer 16R1488 (Mellado et al., 1995). Direct sequence determination of the PCRamplified DNA was carried out by using an automated DNA sequencer (model ABI 3130XL; Applied Biosystems). The 16S rRNA gene sequence analysis was performed with the ARB software package (Ludwig et al., 2004). The $16 \mathrm{~S}$ rRNA gene sequence was aligned with those of phylogenetically closely related organisms (as determined by BLAST and EzTaxon analyses) (Maidak et al., 1996; Chun et al., 2007) and the alignment was confirmed and checked against both primary and secondary structures of the $16 \mathrm{~S}$ rRNA molecule using the alignment tool of the ARB software package. The phylogenetic trees were constructed using three different methods: maximum-likelihood (Felsenstein, 1981), maximum-parsimony (Fitch, 1971) and neighbour-joining (Saitou \& Nei, 1987) algorithms integrated in the ARB software for phylogenetic inference. The 16S rRNA gene sequences used for phylogenetic comparisons were obtained from the GenBank database and the strain designations and their accession numbers are shown in Fig. 1.

The almost-complete 16S rRNA gene sequence of strain HS2 $6^{\mathrm{T}}$ (1453 nucleotides) was obtained and used for initial BLAST and EzTaxon searches in GenBank and phylogenetic analysis. Comparative $16 \mathrm{~S}$ rRNA gene sequence analysis revealed that strain $\mathrm{HS}_{2} 86^{\mathrm{T}}$ was most closely related to the genus Thalassobacillus. In the phylogenetic tree based on the neighbour-joining algorithm (Fig. 1), strain $\mathrm{HS}_{286^{\mathrm{T}}}$ formed a separate cluster with Thalassobacillus devorans G-19.1 ${ }^{\mathrm{T}}$, the sole species of the genus Thalassobacillus so far described. This separate branch was phylogenetically related to a cluster that included species of the genera Halobacillus and Salimicrobium. The highest degree of $16 \mathrm{~S}$ rRNA gene sequence similarity was found with $T$. devorans $(99.4 \%)$, followed by Halobacillus yeomjeoni (96.9\%), Halobacillus alkaliphilus (96.7\%) and Halobacillus campisalis (96.5\%). The similarity values between strain $\mathrm{HS}^{2} 26^{\mathrm{T}}$ and the type 
Table 1. Characteristics that distinguish strain $\mathrm{HS}_{2} 86^{\top}$ from species of the genus Thalassobacillus and closely related species of the genus Halobacillus

Strains: 1, Thalassobacillus cyri sp. nov. HS286 ${ }^{\mathrm{T}}$; 2, Thalassobacillus devorans G-19.1 ${ }^{\mathrm{T}}$ (data from García et al., 2005); 3, Halobacillus yeomjeoni MSS-402 ${ }^{\mathrm{T}}$ (Yoon et al., 2005); 4, Halobacillus alkaliphilus $\mathrm{FP}^{\mathrm{T}}$ (Romano et al., 2008); 5, Halobacillus campisalis ASL-17 ${ }^{\mathrm{T}}$ (Yoon et al., 2007). + , Positive; -, negative; ND, not determined.

\begin{tabular}{|c|c|c|c|c|c|}
\hline Characteristic & 1 & 2 & 3 & 4 & 5 \\
\hline Cell size $(\mu \mathrm{m})$ & $0.6-0.8 \times 1.3-8.5$ & $1.0-1.2 \times 2.0-4.0$ & $0.4-0.6 \times 2.0-10.0$ & 1.57 (diameter) & $0.7-1.4 \times 1.0-1.6$ \\
\hline Oxidase & + & - & + & + & + \\
\hline Range for growth & $1-15$ & $0.5-20$ & $0.5-21$ & $0.5-20$ & $0-22$ \\
\hline Optimum $(\%, w / v)$ & 8 & $7.5-10$ & $3-5$ & 10 & 8 \\
\hline \multicolumn{6}{|l|}{ Temperature $\left({ }^{\circ} \mathrm{C}\right)$} \\
\hline Optimum & 40 & 37 & 37 & 37 & 37 \\
\hline \multicolumn{6}{|l|}{$\mathrm{pH}$} \\
\hline Range & $7.0-9.5$ & $6.0-10.0$ & $5.5-8.0$ & $6.0-10.0$ & $5.5-\mathrm{ND}$ \\
\hline Optimum & 7.5 & 7.0 & $7.0-8.0$ & 9.0 & $7.0-8.0$ \\
\hline Acid production from melibiose & + & - & - & $\mathrm{ND}$ & + \\
\hline Methyl red test & + & - & ND & ND & ND \\
\hline Starch & + & - & - & - & + \\
\hline Diamino acid in peptidoglycan & $m-\mathrm{Dpm}^{\star}$ & $m$-Dpm & Orn-D-Asp & Orn-D-Asp & $m$-Dpm \\
\hline DNA G $+C$ content $(\mathrm{mol} \%)$ & 43.0 & 42.4 & 42.9 & 43.5 & 42.1 \\
\hline
\end{tabular}

${ }^{\star} m$-Dpm, meso-diaminopimelic acid.



Fig. 1. Neighbour-joining phylogenetic tree, based on the $16 \mathrm{~S}$ rRNA gene sequence comparison, showing the relationship of strain $\mathrm{HS}_{286^{\top}}$ with related species. The accession numbers of the sequences used in this study are shown in parentheses after the strain designation. Paenibacillus polymyxa NCDO $1774^{\top}$ (X60632) was used as an outgroup. Bar, 0.01 substitutions per nucleotide position. 
strains of other species of the genus Halobacillus were 96.3$93.5 \%$. The novel strain showed $94.0-91.8 \%$ gene sequence similarity with the three species of the genus Salimicrobium. Similar tree topologies were obtained when other treeing methods (maximum-parsimony and maximum-likelihood) were used (results not shown).

The $\mathrm{G}+\mathrm{C}$ content of the genomic DNA was determined from the midpoint value $\left(T_{\mathrm{m}}\right)$ of the thermal denaturation profile (Marmur \& Doty, 1962) by using the equation of Owen \& Hill (1979). Cell biomass for analyses of cell-wall peptidoglycan, isoprenoid quinones, polar lipids and fatty acids was obtained by cultivation on HM medium at $37^{\circ} \mathrm{C}$. Cell-wall peptidoglycan type, polar lipids and the menaquinone type of strain HS286 ${ }^{\mathrm{T}}$ were analysed by the Identification Service of the DSMZ (Braunschweig, Germany). The whole-cell fatty acid composition was determined by GC using the Microbial Identification System (MIDI, Microbial ID). This analysis was performed by the Identification, Characterization and Molecular Typing Service of the BCCM/LMG bacteria collection (Gent, Belgium).

The DNA G + C content of strain $\mathrm{HS}_{28} 6^{\mathrm{T}}$ was $43.0 \mathrm{~mol} \%$, which was close to the value previously described for $T$. devorans ( $42.4 \mathrm{~mol} \%$ ) (García et al., 2005). Strain HS286 ${ }^{\mathrm{T}}$ had cell-wall peptidoglycan based on meso-diaminopimelic acid as the diagnostic diamino acid, similar to that described for T. devorans (García et al., 2005). However, this feature distinguished strain $\mathrm{HS} 286^{\mathrm{T}}$ from the majority of the species included in the genus Halobacillus, which have been described as having a cell-wall peptidoglycan type based on L-Orn-D-Asp (Amoozegar et al., 2003; An et al., 2007; Hua et al., 2007; Liu et al., 2005; Spring et al., 1996; Yoon et al., 2003, 2004, 2005). H. campisalis is the sole species belonging to the genus Halobacillus with a cellwall peptidoglycan type based on meso-diaminopimelic acid (Yoon et al., 2007); however, this species is distantly related to our novel isolate $(96.5 \%$ gene sequence similarity). The isoprenoid quinone detected in strain HS286 ${ }^{\mathrm{T}}$ was menaquinone-7 (MK-7). With respect to the polar lipid composition, strain HS286 ${ }^{\mathrm{T}}$ contained diphosphatidylglycerol, phosphatidylglycerol, two phospholipids and a glycolipid. These chemotaxonomic features of the new isolate are similar to those of T. devorans DSM $16966^{\mathrm{T}}$ (García et al., 2005). The major fatty acids of strain HS286 ${ }^{\mathrm{T}}$ were anteiso- $\mathrm{C}_{15: 0}(43.8 \%)$, iso- $\mathrm{C}_{16: 0}(21.4 \%)$, iso- $\mathrm{C}_{14: 0}$ $(9.4 \%)$, anteiso- $\mathrm{C}_{17: 0}(8.7 \%)$ and iso- $\mathrm{C}_{15: 0}(7.0 \%)$ (Table 2). Only some minor differences in the proportions of the fatty acids were observed with respect to $T$. devorans (Table 2).

DNA-DNA hybridization studies were performed by the competition procedure of the membrane filter method (Johnson, 1994). The hybridization temperature was $47.3{ }^{\circ} \mathrm{C}$, which is within the limit of validity for the filter method (De Ley \& Tijtgat, 1970) and the percentage of hybridization was calculated according to Johnson (1994). The experiments were performed in triplicate. The
Table 2. Cellular fatty acid content (\%) of strain $\mathrm{HS}^{286^{\top}}$ and the most closely related species

Strains: 1, Thalassobacillus cyri sp. nov. $\mathrm{HS}_{2} 86^{\mathrm{T}}$; 2. T. devorans G-19.1 ${ }^{\mathrm{T}}$ (García et al., 2005; M. T. García, personal communication).

\begin{tabular}{|lcc|}
\hline Fatty acid & $\mathbf{1}$ & $\mathbf{2}$ \\
\hline iso- $\mathrm{C}_{14: 0}$ & 9.4 & 4.8 \\
Summed feature $2^{*}$ & 2.1 & - \\
iso- $\mathrm{C}_{15: 0}$ & 7.0 & 10.2 \\
anteiso- $\mathrm{C}_{15: 0}$ & 43.8 & 52.3 \\
iso- $\mathrm{C}_{16: 0}$ & 21.4 & 10.5 \\
$\mathrm{C}_{16: 1} \omega 17 c$ & 1.4 & 0.45 \\
$\mathrm{C}_{16: 0}$ & 0.4 & 0.64 \\
iso- $\mathrm{C}_{17: 0}$ & 1.8 & 1.4 \\
anteiso-C & 8.7 & 8.3 \\
anteiso- $\mathrm{C}_{17: 1}$ & 2.8 & 5.1 \\
\hline
\end{tabular}

${ }^{*}$ Summed feature $2: \mathrm{C}_{12: 0}$ alde, iso- $\mathrm{C}_{16: 1} / \mathrm{C}_{14: 0} 3-\mathrm{OH}$.

percentage of DNA-DNA hybridization between strain HS286 ${ }^{\mathrm{T}}$ and T. devorans $\mathrm{G}-19.1^{\mathrm{T}}$ was $27.3 \%$. These levels of DNA-DNA hybridization are low enough to classify strain $\mathrm{HS}^{286^{\mathrm{T}}}$ as a genotypically distinct species within the genus Thalassobacillus (Stackebrandt \& Goebel, 1994; Stackebrandt et al., 2002).

$16 \mathrm{~S}$ rRNA gene sequence analysis revealed that strain $\mathrm{HS}_{286^{\mathrm{T}}}$ is closely related to T. devorans G-19.1 ${ }^{\mathrm{T}}$, constituting a separate branch with respect to the other closely related species, members of the genera Halobacillus, Salimicrobium and other Firmicutes. Strain $\mathrm{HS}_{2} 86^{\mathrm{T}}$ shared some phenotypic features and similar chemotaxonomic characteristics, such as the cell-wall peptidoglycan type, respiratory lipoquinone, polar lipid and fatty acid composition, with the genus Thalassobacillus. However, there are several phenotypic features that differentiate the novel strain from $T$. devorans (shown in Table 1), as well as different reactions for the utilization of D-glucose, Dgalactose, glycerol, D-ribose, melibiose, D-alanine and Lasparagine as sole source of carbon and energy. In addition, the DNA-DNA hybridization data clearly support the suggestion that strain $\mathrm{HS} 286^{\mathrm{T}}$ constitutes a separate species from T. devorans. Based on the data presented, we propose to place the new isolate as a novel species with the name Thalassobacillus cyri sp. nov.

\section{Description of Thalassobacillus cyri sp. nov.}

Thalassobacillus cyri (cy'ri. L. masc. gen. n. cyri of Cyrus, named after Cyrus, the first king of Persia, where the type strain was isolated).

Cells are Gram-positive, motile, endospore-forming rods, $0.6-0.8 \times 1.3-8.5 \mu \mathrm{m}$ in size. Ellipsoidal endospores are produced at a central-subterminal position in swollen sporangia. Colonies are circular, entire, smooth, creambeige and are $2 \mathrm{~mm}$ in diameter on $10 \% \mathrm{HM}$ agar medium 
after $48 \mathrm{~h}$ incubation at $37{ }^{\circ} \mathrm{C}$. Strictly aerobic. Moderately halophilic, growing at $1-15 \%(\mathrm{w} / \mathrm{v}) \mathrm{NaCl}$, with optimal growth at $8 \%(\mathrm{w} / \mathrm{v}) \mathrm{NaCl}$. No growth occurs in the absence of $\mathrm{NaCl}$. Grows at $5-45{ }^{\circ} \mathrm{C}$ (optimally at $40{ }^{\circ} \mathrm{C}$ ) and at pH 7.0-9.5 (optimally at $\mathrm{pH} 7.5$ ). Catalase- and oxidase-positive. Casein, starch, DNA, aesculin and Tween 80 are hydrolysed but gelatin is not hydrolysed. Nitrate is reduced to nitrite but nitrite is not reduced. Acid is produced from D-fructose, D-glucose, galactose, D-mannose, maltose, melibiose and trehalose but not from myoinositol, lactose or D-xylose. Methyl red test is positive and lysine decarboxylase and arginine dihydrolase activities are positive. Indole or $\mathrm{H}_{2} \mathrm{~S}$ are not produced. VogesProskauer, urease, $\beta$-galactosidase, ornithine decarboxylase and phenylalanine deaminase tests are negative. The following compounds are utilized as sole source of carbon and energy: D-fructose, galactose, lactose, maltose, Dmannose, melibiose, D-ribose, sucrose, glycerol, alanine, arginine, asparagine, cysteine, leucine and proline. The following compounds are not utilized as sole source of carbon and energy: D-glucose, myo-inositol, glycine, lysine, methionine and valine. Sensitive to amoxicillin $(30 \mu \mathrm{g})$, carbenicillin $(100 \mu \mathrm{g})$, gentamicin $(30 \mu \mathrm{g})$, nitrofurantoin $(300 \mu \mathrm{g})$, tetracycline $(30 \mu \mathrm{g})$, rifampicin $(5 \mu \mathrm{g})$ and polymixin B $(100 \mathrm{U})$. Resistant to tobramycin $(10 \mu \mathrm{g})$ and kanamycin $(30 \mu \mathrm{g})$. Polar lipids are diphosphatidylglycerol, phosphatidylglycerol, two phospholipids and a glycolipid. The isoprenoid quinone is MK-7. The cell-wall peptidoglycan type is A1 $\gamma$, with meso-diaminopimelic acid as the diagnostic diamino acid. The major cellular fatty acids are anteiso- $\mathrm{C}_{15: 0}$, iso- $\mathrm{C}_{16: 0}$, iso- $\mathrm{C}_{14: 0}$, anteiso- $\mathrm{C}_{17: 0}$ and iso- $\mathrm{C}_{15: 0}$.

The type strain, HS286 ${ }^{\mathrm{T}}\left(=\mathrm{CCM} 7597^{\mathrm{T}}=\mathrm{JCM} 15722^{\mathrm{T}}\right)$, was isolated from the Howz-Soltan hypersaline lake in Iran. The DNA G + C content of the type strain is $43.0 \mathrm{~mol} \%$ $\left(T_{\mathrm{m}}\right)$.

\section{Acknowledgements}

We are grateful to J. Euzéby for his help and valuable suggestions regarding the etymology. This study was supported by grants from the Iranian Environment Department (3/42274), the Spanish Ministerio de Educación y Ciencia (BIO2006-06927) and Junta de Andalucía (P06-CVI-01829).

\section{References}

Amoozegar, M. A., Malekzadeh, F., Malik, K. A., Schumann, P. \& Spröer, C. (2003). Halobacillus karajensis sp. nov., a novel moderate halophile. Int J Syst Evol Microbiol 53, 1059-1063.

An, S.-Y., Kanoh, K., Kasai, H., Goto, K. \& Yokota, A. (2007). Halobacillus faecis sp. nov., a spore-forming bacterium isolated from a mangrove area on Ishigaki Island, Japan. Int J Syst Evol Microbiol 57, 2476-2479.

Arahal, D. R. \& Ventosa, A. (2002). Moderately halophilic and halotolerant species of Bacillus and related genera. In Applications and Systematics of Bacillus and Relatives, pp. 83-99. Edited by R. Berkeley, M. Heyndrickx, N. Logan \& P. De Vos. Oxford: Blackwell.
Baron, E. J. \& Finegold, S. M. (1990). Bailey and Scott's Diagnostic Microbiology, 8th edn. St Louis: Mosby.

Chun, J., Lee, J.-H., Jung, Y., Kim, M., Kim, S., Kim, B. K. \& Lim, Y.-W. (2007). EzTaxon: a web-based tool for the identification of prokaryotes based on $16 \mathrm{~S}$ ribosomal RNA gene sequences. Int J Syst Evol Microbiol 57, 2259-2261.

De Ley, J. \& Tijtgat, R. (1970). Evaluation of membrane filter methods for DNA-DNA hybridization. Antonie van Leeuwenhoek 36, 461-474.

Felsenstein, J. (1981). Evolutionary trees from DNA sequences: a maximum likelihood approach. J Mol Evol 17, 368-376.

Fitch, W. M. (1971). Toward defining the course of evolution: minimum change for a specific tree topology. Syst Zool 20, 406-416.

García, M. T., Gallego, V., Ventosa, A. \& Mellado, E. (2005). Thalassobacillus devorans gen. nov., sp. nov., a moderately halophilic, phenol-degrading, Gram-positive bacterium. Int J Syst Evol Microbiol 55, 1789-1795.

Harrigan, W. F. \& McCance, M. E. (1976). Laboratory Methods in Food and Dairy Microbiology. London: Academic Press.

Hua, N.-P., Kanekiyo, A., Fujikura, K., Yasuda, H. \& Naganuma, T. (2007). Halobacillus profundi sp. nov., and Halobacillus kuroshimensis sp. nov., moderately halophilic bacteria isolated from a deep-sea methane cold seep. Int J Syst Evol Microbiol 57, 1243-1249.

Johnson, J. L. (1994). Similarity analysis of DNAs. In Methods for General and Molecular Bacteriology, pp. 655-681. Edited by P. Gerhardt, R. G. E. Murray, W. A. Wood \& N. R. Krieg. Washington, DC: American Society for Microbiology.

Liu, W. Y., Zeng, J., Wang, L., Dou, Y. T. \& Yang, S. S. (2005). Halobacillus dabanensis sp. nov. and Halobacillus aidingensis sp. nov., isolated from salt lakes in Xinjiang, China. Int J Syst Evol Microbiol 55, 1991-1996.

Ludwig, W., Strunk, O., Westram, R., Richter, L., Meier, H., Yadhukumar, Buchner, A., Lai, T., Steppi, S. \& other authors (2004). ARB: a software environment for sequence data. Nucleic Acids Res 32, 1363-1371.

Maidak, B. L., Olsen, G. J., Larsen, N., Overbeek, R., McCaughey, M. J. \& Woese, C. R. (1996). The Ribosomal Database Project (RDP). Nucleic Acids Res 24, 82-85.

Marmur, J. (1961). A procedure for the isolation of deoxyribonucleic acid from microorganisms. J Mol Biol 3, 208-218.

Marmur, J. \& Doty, P. (1962). Determination of the base composition of deoxyribonucleic acid from its thermal denaturation temperature. $J$ Mol Biol 5, 109-118.

Mata, J. A., Martinez-Canovas, J., Quesada, E. \& Bejar, V. (2002). A detailed phenotypic characterization of the type strains of Halomonas species. Syst Appl Microbiol 25, 360-375.

Mellado, E., Moore, E. R. B., Nieto, J. J. \& Ventosa, A. (1995). Phylogenetic inferences and taxonomic consequences of $16 \mathrm{~S}$ ribosomal DNA sequence comparison of Chromohalobacter marismortui, Volcaniella eurihalina and Deleya salina, and reclassification of $V$. eurihalina as Halomonas eurihalina comb. nov. Int J Syst Bacteriol 45, 712-716.

Murray, R. G. E., Doetsch, R. N. \& Robinow, F. (1994). Determinative and cytological light microscopy. In Methods for General and Molecular Bacteriology, pp. 21-41. Edited by P. Gerhardt, R. G. E. Murray, W. A. Wood \& N. R. Krieg. Washington, DC: American Society for Microbiology.

Owen, R. J. \& Hill, L. R. (1979). The estimation of base compositions, base pairing and genome sizes of bacterial deoxyribonucleic acids. In Identification Methods for Microbiologists (Society for Applied Bacteriology Technical Series no. 14), 2nd edn, pp. 277-296. Edited by F. A. Skinner \& D. W. Lovelock. London: Academic Press. 
Quesada, E., Ventosa, A., Ruiz-Berraquero, F. \& RamosCormenzana, A. (1984). Deleya halophila, a new species of moderately halophilic bacteria. Int J Syst Bacteriol 34, 287-292.

Romano, I., Finore, I., Nicolaus, G., Huertas, F. J., Lama, L., Nicolaus, B. \& Poli, A. (2008). Halobacillus alkaliphilus sp. nov., a halophilic bacterium isolated from a salt lake in Fuente de Piedra, southern Spain. Int J Syst Evol Microbiol 58, 886-890.

Saitou, N. \& Nei, M. (1987). The neighbour-joining method: a new method for reconstructing phylogenetic trees. Mol Biol Evol 4, 406-425.

Smibert, R. M. \& Krieg, N. R. (1994). Phenotypic characterization. In Methods for General and Molecular Bacteriology, pp. 607-654. Edited by P. Gerhardt, R. G. E. Murray, W. A. Wood \& N. R. Krieg. Washington, DC: American Society for Microbiology.

Spring, S., Ludwig, W., Marquez, M. C., Ventosa, A. \& Schleifer, K. H. (1996). Halobacillus gen. nov., with descriptions of Halobacillus litoralis sp. nov. and Halobacillus trueperi sp. nov., and transfer of Sporosarcina halophila to Halobacillus halophilus comb. nov. Int J Syst Bacteriol 46, 492-496.

Stackebrandt, E. \& Goebel, B. M. (1994). Taxonomic note: a place for DNA-DNA reassociation and $16 \mathrm{~S}$ rRNA sequence analysis in the present species definition in bacteriology. Int J Syst Bacteriol 44, 846-849.

Stackebrandt, E., Fredericksen, W., Garrity, G. M., Grimont, P. A. D., Kämpfer, P., Maiden, M. C. J., Nesme, X., Rossello-Mora, R., Swings, J. \& other authors (2002). Report of the ad hoc committee for the re-evaluation of the species definition in bacteriology. Int $J$ Syst Evol Microbiol 52, 1043-1047.

Ventosa, A. (2006). Unusual micro-organisms from unusual habitats: hypersaline environments. In Prokaryotic diversity: Mechanisms and Significance, pp. 223-253. Edited by N. A. Logan, H. M. Lappin-Scott \& P. C. F. Oyston. Cambridge: Cambridge University Press.

Ventosa, A., Quesada, E., Rodriguez-Valera, F., Ruiz-Berraquero, F. \& Ramos-Cormenzana, A. (1982). Numerical taxonomy of moderately halophilic Gram-negative rods. J Gen Microbiol 128, 1959-1968.

Ventosa, A., Nieto, J. J. \& Oren, A. (1998). Biology of moderately halophilic aerobic bacteria. Microbiol Mol Biol Rev 62, 504-544.

Yoon, J.-H., Kang, K. H. \& Park, Y.-H. (2003). Halobacillus salinus sp. nov., isolated from a salt lake on the coast of the East Sea in Korea. Int J Syst Evol Microbiol 53, 687-693.

Yoon, J.-H., Kang, K. H., Oh, T.-K. \& Park, Y.-H. (2004). Halobacillus locisalis sp. nov., a halophilic bacterium isolated from a marine solar saltern of the Yellow Sea in Korea. Extremophiles 8, 23-28.

Yoon, J.-H., Kang, K. H., Lee, C.-H., Oh, H.-W. \& Oh, T.-K. (2005). Halobacillus yeomjeoni sp. nov., isolated from a marine solar saltern in Korea. Int J Syst Evol Microbiol 55, 2413-2417.

Yoon, J.-H., Kang, J. K., Jung, Y.-T. \& Oh, T.-K. (2007). Halobacillus campisalis sp. nov., containing meso-diaminopimelic acid in the cellwall peptidoglycan, and emended description of the genus Halobacillus. Int J Syst Evol Microbiol 57, 2021-2025. 